\title{
Effect of Technology Based Financial Innovations on Non-Interest Income of Commercial Banks in Kenya
}

\author{
L'souza Boniface Alubisia \\ Postgraduate student, University of Nairobi, Kenya \\ Wainaina Githii, PhD \\ University of Nairobi, School of Business, \\ Department of Management Science, Kenya \\ Mirie Mwangi, PhD \\ University of Nairobi, School of Business, \\ Department of Finance and Accounting, Kenya
}

Doi: 10.19044/esj.2018.v14n7p337 URL:http://dx.doi.org/10.19044/esj.2018.v14n7p337

\begin{abstract}
Technology based financial innovation has had a great impact on the financial industry as a whole over the past few decades. It has presented the banking sector with an opportunity to increase the revenue base. This study intended to identify the impact of technology based financial innovation on non-interest income in Kenyan commercial banks. The study investigated how the adoption of ATMs and Cards, Internet and Mobile Banking and use of Funds Transfer Systems such as RTGS and EFT has impacted the non-interest income of commercial banks in Kenya. Descriptive research design was utilised. The study found that technology based financial innovation has significant effect on the non-interest income earned by commercial banks in Kenya. It recommends all stakeholders in commercial banks to take any investments made towards technology based financial innovation products as a strategy to improve non-interest income.
\end{abstract}

Keywords: Technology, Financial Innovation, Non-interest income, Commercial Banks

\section{Introduction}

Due to technology advancement and globalisation, the past few decades have seen change in traditional banking. This has made it possible for financial organizations to offer financial services that live up to the expectations of a changing generation (Beck, Chen, Lin and Song, 2016). One direct consequence is financial innovation which has not only redefined modern market economies but has also popularised new financial instruments 
that offer better lending and borrowing systems and payment mechanisms. According to the International Monetary Fund, financial innovation has resulted to the emergence of vital services that evaluate, allocate and monitor the use of capital, while enhancing transactions and risk management. These improvements have resulted to significant changes in the demographics of the operation of commercial banks all over the world. As at 2016, there were 3.6 billion automatic teller machines (ATM) in the world, increasing the amount of income commercial institutions earn from the use of these machines (ATM Benchmarking Study and Industry Report, 2016).

However, challenges have been experienced as far as moving from traditional banking into the rather fast and sophisticated banking that integrates financial innovation (Laeven, Levine and Michalopoulos, 2015). This study intends to highlight the relationship between financial innovation and noninterest income. For instance, banks have had to introduce mobile applications and Smart ATMs to replace human tellers, internet banking to eradicate the problem of geographical distance as well as the emerging digital peer-to-peer banking. All these have had various effects on the way banks earn their noninterest income (Shaikh and Karjaluoto, 2015). It is evident that an influx of financial needs has been created by this new seamless financial environment that makes it relatively easy and convenient to make transactions. First, the internet has offered a complete overhaul of how individuals and co-operations access financial services. New securities have been provided through this platform, which has greatly facilitated the movement of capital to the most required areas of investment leading to economic growth. Commercial banking is therefore changing, thus the need to understand the relationship between technologies based financial innovation and non-interest income (Beck, Chen, Lin and Song, 2016). These emergent relationships are explained through various theories that are based on financial innovation. These are the diffusion of innovation theory, disruptive innovation theory and market efficiency theory of innovation. These theories explain different aspects of financial innovation and its relationship with commercial banking.

Technology based financial innovation can be considered as an act that leads to the creation and popularization of new financial systems that are almost entirely based on Information Technology (IT), risk transfer and credit and equity generation (Beck, Chen, Lin and Song, 2016). These new systems are often characterised by reduced cost, lower risks, improved services, increased security, better flow of capital to areas of investment and more importantly an improved financial service sector that accelerates economic growth. There are several technology based financial innovations that have been developed, including ATMs, credit and debit cards, online and mobile banking applications as well as funds transfer systems (FTS) such as real time gross settlement (RTGS) and electronic funds transfers (EFT). 
An ATM is basically a computer terminal that comprises of a cash vault and a record keeping system capable of holding records of account information. An individual looking to utilise ATM services should have a credit or debit card that has a chip with their account information as well as their Personal Identification Number (PIN) that will communicate with the ATM computer and allow the transaction (Shaikh and Karjaluoto, 2015). The ATM offers a number of services to its users including the ability to withdraw, deposit, pay utility bills or transfer cash from one geographical location to another electronically. They are widespread, and need not be physically located near banking institutions. Online banking is a service provided by a commercial bank that allows customers to conduct financial transactions as if they were physically present in a banking hall while in reality they are using their mobile phones (Shaikh \& Karjaluoto, 2015). It entails accessing banking services via the internet and hence also referred to as internet banking (YeeLoong Chong, Ooi, Lin and Tan, 2010). This means, banking services (such as accessing accounts, checking balances, point of sale purchases and transfer of large amounts of money via EFT) that would otherwise be only available in a banking hall are accessible remotely. It uses software in the form of an app that is provided by the financial institution to the customer for the sole purpose of transacting. Finally, FTS comprises of systems that facilitate the transfer of large amounts of money from one institution to another (Worku, 2010) and includes RTGS and EFT. RTGS enables the movement of funds from one banking institution to another in such a way that the settlement is in real time i.e. transactions are not subjected to time and take place instantly. In essence, settlements are completed as soon as they are processed on a one to one basis, eliminating the need for netting with any other transaction at the bank. This has revolutionised transactions that are of high-value and require immediate settlement. On the other hand, EFT is a form of electronic funds transfer that also handles high-value transactions. However, settlements done through this system are not real time but also rely on a network to function (Jack, Suri \& Townsend, 2010).

Traditionally, the main sources of income for financial institutions have been in the form of interests charged on loans and investments in various government and rated securities. This is because the core business of banks is to sell cash. However, non-interest income is fast emerging as the sole source of interest given the fact that interest earning sources are often capped by the government or they have a tendency to fluctuate from high to low. NonInterest income can be defined as creditor income derived from several fees charged upon offering services. These include fees from deposits, transactions from credit and debit cards, inactivity fees, monthly or annual service charge fees as well as insufficient fund fees. This income can also be in the form of asset sales, or penalties that are associated with withdrawals of overdrafts. Fees 
from the use of ATM's, credit and debit cards, as well as transactions made over the counter all fall under this category. It should be noted that the main drivers behind this income is the economic environment. For instance, in order for a financial institution to successfully trade securities or even provide equity financing to an organization, there are certain economic variables that have to be favourable (Williams, 2016). The movement of both domestic and foreign funds from one market to another has also become a profitable service for financial institutions today. Indeed, money can now be transferred from one place to another regardless of geographical location or time zone differences by use of EFT as well as rapid transfer (Lee, Yang and Chang, 2014). This involves the use of money orders, demand drafts and bankers cheques from one institution to another. All these sources of income have made it possible for financial institutions to be able to break even in a rather competitive financial industry. Moreover, they help the banks remain liquid in today's environment where default rates among customers are high (Central Bank of Kenya, 2016).

Three main Acts of Parliament that regulate the Kenyan banking sector are the Companies Act, the Central Bank of Kenya Act and the Banking Act. In addition the Central Bank issues prudential guidelines to guide the day to day operations of banks, bureaus and micro-finance institutions. The sector comprises 43 commercial banks, 109 forex bureaus and 15 micro-finance institutions as at the end of December 2016 (Central Bank of Kenya, 2016). As such, this study concentrated on the 43 banks in the land. The Central Bank of Kenya (2016) asserts that thirty (30) of the forty three (43) banks are domestically owned while thirteen (13) are foreign operated. This report also points out that foreign banking institutions accounted for approximately $39 \%$ of the banking assets as of end of 2016. It is also important to note that all banks are under an umbrella body, the Kenya Bankers Association (KBA) which works with banks to ensure that the interests of the banks are well represented. The association also provides a platform for addressing sectoral issues, including the grievances of employees or relationship with the government (Central Bank of Kenya, 2016).

Despite the discussed benefits of technological advancement, rapid financial innovation can also pose a potential systemic risk. A rapid expansion of financial products that do not have a proven track record often fools investors into ignoring the risks associated with it (Beck, Chen, Lin and Song, 2016). This can have drastic consequences especially in periods of economic stress. The financial crisis of 2007 - 2009 serves as a reminder of the possibility of such an occurrence. During the crisis, it was observed that many individuals as well as institutions underestimated the risks that would emerge due to new financial products in the global market. Consequently, key markets for liquidity, such as the interbank lending market were affected. From the 
aforegoing, whereas financial institutions ought to take advantage of this innovation in an effort to maintain a desirable balance in their books, key risk measures should be taken to ensure that they do not venture in products that will affect ability to earn non-interest income. To enable innovation to continue benefiting future societies, there is need for setting up of prudential regulations aimed at discouraging taking of excessive risk in the future (Williams, 2016).

\section{Research Problem}

While earnings from lending money are important to banks, trends in the financial industry suggest that this form of income alone is not enough to sustain financial institutions economically. These institutions need to look out for additional sources of income (Chen, Huang and Zhang, 2017). These sources include, but are not limited to, non-interest-income. It has since become the primary way in which these institutions generate income even though it is viewed upon as a strategic line-item on the income statement. It is important to note that non-interest income channels entirely comprise technologically based financial innovation. As such, technologically based financial innovation is at the heart of commercial banks' business as they seek to profit from non-interest income (Beck, Chen, Lin and Song, 2016).

Several global studies have been carried out to elaborate the relationship between technology driven financial innovation and non-interest income. Frame and White (2014) investigated technological change, financial innovation, and diffusion in the banking sector. They acknowledged that as a result of technological changes, over the past 30 years, the market has witnessed significant developments in commercial banking. Their study highlighted that not much has been brought to light as to the manner and justification for developing financial innovations and how they actually impact a bank's income and that much effort has been directed towards uncovering the behaviours of different users of technology based innovations in the financial sector and how these developments affect the welfare of individuals and societies (Frame \& White, 2014). Beck, Chen, Lin and Song (2016) found that financial institutions tend to flourish in countries where securities are large and also where the regulatory frameworks are more restricted. Kenyan studies have also been done to elaborately explain this relationship. For instance, Gichure, (2015) studied the relationship between non-interest income and financial performance of commercial banks in Kenya. The study concluded that non-interest income positively contributes to the financial performance of commercial banks in Kenya. Based on this conclusion, the study recommended a heightened focus on management and monitoring of noninterest income activities if banks are to register an increase in performance. Kamau, (2014) investigated the effect of cashless transactions and financial 
trading income on non-funded income in commercial banks in Kenya. The study revealed that cashless transactions income and financial trading income have a positive effect on non- funded income in commercial banks in Kenya. As such, the study recommends that banks should conduct research on other viable avenues of non-interest income to banks, including the use of ATMs, mobile banking, internet banking and the use of financial innovation systems to generate income.

Although these studies have established the correlation between financial performance and technology based innovation, the extent to which this innovation affect financial income that banks make has not been brought out clearly. This study intended to find this extent by first highlighting the current state of adoption of technology based innovation in commercial banks in Kenya. Moreover, provide a comparison of the non-interest income from technology based innovation products and non-interest income from other sources like fees and penalties. This should show the difference in income earned by banks from both sources, thereby giving the proportion of income attributed to non-interest sources.

\section{Methodology}

Descriptive analysis was used to describe the nature of the data collected, while a multiple regression model was developed and a multiple regression analysis conducted to illustrate the relationship between the independent and dependent variables. The multiple regression model took the following format;

$$
Y=\beta_{0}+\beta_{1} X_{1}+\beta_{2} X_{2}+\beta_{3} X_{3}+\beta_{4} X_{4}+\varepsilon
$$

Where $\mathrm{Y}=$ Non-Interest Income (Amount of Income from Non-interest sources)

$\mathrm{X}_{1}=$ Income generated from ATMs and Debit/Credit Cards

$\mathrm{X}_{2}=$ Income generated from Online Banking

$\mathrm{X}_{3}=$ Income generated from Mobile Banking

$\mathrm{X}_{4}=$ Income generated from Funds Transfer System

\section{Results and Discussion}

Correlation tests to establish the relationship between the variables are summarised in Table 1. 
Table 1: Correlation Test Results

\begin{tabular}{|c|c|c|c|c|c|c|}
\hline & LNNIR & LNATMC & LNOB & LNMB & LNFTS \\
\hline \multirow[t]{3}{*}{ LNNIR } & Pearson Correlation & & & & & \\
\hline & Sig. (2-tailed) & & & & & \\
\hline & $\mathrm{N}$ & 44 & & & & \\
\hline \multirow[t]{3}{*}{ LNATMC } & Pearson Correlation & $.805^{* *}$ & & & & \\
\hline & Sig. (2-tailed) & .001 & & & & \\
\hline & $\mathrm{N}$ & 44 & 44 & & & \\
\hline \multirow[t]{3}{*}{ LNOB } & Pearson Correlation & $.594^{* * *}$ & $.381^{* *}$ & & & \\
\hline & Sig. (2-tailed) & .001 & .000 & & & \\
\hline & $\mathrm{N}$ & 44 & 44 & 44 & & \\
\hline \multirow[t]{3}{*}{ LNMB } & Pearson Correlation & $.514^{* * *}$ & .255 & .231 & & \\
\hline & Sig. (2-tailed) & .000 & .875 & .909 & & \\
\hline & $\mathrm{N}$ & 44 & 44 & 44 & 44 & \\
\hline \multirow[t]{3}{*}{ LNFTS } & Pearson Correlation & $.651^{* * *}$ & $.244^{*}$ & .301 & $.431^{*}$ & \\
\hline & Sig. (2-tailed) & .000 & .078 & .101 & .080 & \\
\hline & $\mathrm{N}$ & 44 & 44 & 44 & 44 & 44 \\
\hline
\end{tabular}

Where LNNIR =Natural log of Non-Interest Income

LNATMC $=$ Natural log of Income generated from ATMs and Debit/Credit Cards

$\mathrm{LNMB}=$ Natural log of Income generated from Online Banking

$\mathrm{LNOB}=$ Natural log of Income generated from Mobile Banking

LNFTS $=$ Natural log of Income generated from Funds Transfer System

Results indicate that there is a strong positive relationship between Non-Interest Income and amount of funds from ATM's and cards as indicated by a correlation coefficient of $0.805(\mathrm{p}=0.001)$. Its relationship with income from online banking is positive and relatively strong as indicated by a correlation coefficient of $0.594(\mathrm{p}=0.001)$, similar to that of mobile banking $(0.514, \mathrm{p}=0.000)$. Finally, its relationship with income from funds transfer system is equally strong and positive as indicated by a coefficient of 0.651 $(\mathrm{p}=0.000)$. The correlation coefficients between the independent variables indicate a weak but positive relationship which rules out the possibility of multi-correlation.

A basic assumption of the classical linear regression model asserts that variables should have a constant mean, variance and the covariance between the values of two time periods should be zero. Violation of this assumption leads to spurious regression. To avoid this short fall, the unit root test was conducted on the variables to ascertain whether they are stationarity or nonstationary. Augmented Dickey-Fuller (ADF) tests were employed by the study. If a variable is stationary at level, i.e. without running any differencing, then it is said to be integrated of order zero or I (0) and if it becomes stationary after differencing, then the variable is said to be an I (d) variable, where $d$ represents the number of times it has been differenced. The null hypothesis for this test is that the variables are stationary. It is also important to note that the 
study selected the lag length of the ADF test based on the Akaike Information Criterion (AIC) (McMillan and Schumacher, 2014). These results are as displayed in Table 2.

Table 2: Unit Root Tests

\begin{tabular}{|l|c|l|l|l|l|l|}
\hline Variable & \multirow{2}{*}{$\begin{array}{c}\text { Test } \\
\text { statistic }\end{array}$} & $\begin{array}{c}\text { Test statistic } \\
\mathbf{Z}(\mathbf{t}) \text { after First } \\
\text { Order of }\end{array}$ & $\begin{array}{c}\text { Test statistic } \\
\mathbf{Z}(\mathbf{t}) \text { after } \\
\text { level }\end{array}$ & $\begin{array}{c}\text { Orfecond Order } \\
\text { Differencing }\end{array}$ & \multicolumn{3}{|c|}{ Critical value $\mathbf{Z}(\mathbf{t})$} \\
\cline { 5 - 8 } & of Differencing & & & $5 \%$ & $10 \%$ \\
\hline LNNIR & -1.577 & -2.212 & $-4.189^{*}$ & -3.750 & -3.000 & -2.630 \\
\hline LNATMC & -1.731 & -2.653 & $-3.829^{*}$ & -3.750 & -3.000 & -2.630 \\
\hline LNMB & -1.329 & -2.099 & $-4.587^{*}$ & -3.750 & -3.000 & -2.630 \\
\hline LNOB & -3.019 & -1.252 & $-4.368^{*}$ & -3.750 & -3.000 & -2.630 \\
\hline LNFTS & -1.050 & -4.085 & $-4.548^{*}$ & -3.750 & -3.000 & -2.630 \\
\hline
\end{tabular}

Table 2 indicates the test statistic results after first order of differencing and second order differencing. It was observed that at first order differencing, the null hypothesis that each of the time series variables has a unit root was not rejected at order zero (I (0) since their ADF test statistic values are less than critical values at the $1 \%, 5 \%$ and $10 \%$ level of significance. Similarly, upon first order differencing, ADF test statistic values indicated that the null hypothesis that each of the time series variables has a unit root cannot be rejected at first differencing (I (1)) because they were less than the critical values at the $1 \%, 5 \%$ and $10 \%$. However, upon second differencing, the null hypothesis that each of the time series variables has a unit root was rejected because all the ADF test statistic values were greater than the critical values. This shows that all the variables under investigation are individually integrated of order two I (2).

Table 3 indicates that the model had no omitted variables and that their coefficients are significantly different from zero as indicated by a significant calculated $F$ value of 11.821 which is statistically significant as indicated by $\mathrm{p}=0.000<0.05$. This implies that the regression line is a line of good fit.

Table 3: ANOVA Findings

\begin{tabular}{|l|l|l|l|l|l|l|}
\hline \multicolumn{7}{|c|}{ ANOVA $^{\mathbf{a}}$} \\
\hline \multicolumn{2}{|l|}{ Model } & Sum of Squares & df & Mean Square & F & Sig. \\
\hline \multirow{3}{*}{1} & Regression & 1.005 & 4 & .251 & 11.821 & $.000^{\mathrm{b}}$ \\
\cline { 2 - 7 } & Residual & .829 & 39 & .021 & & \\
\cline { 2 - 7 } & Total & 1.833 & 43 & & & \\
\hline \multicolumn{2}{|l|}{ a. Dependent Variable: LNNIR } \\
\hline
\end{tabular}

The multiple regression analysis results are presented in the coefficient Table 4. The study establishes that each technology based financial innovation product has a significant positive effect on non-interest income as indicated by $\mathrm{P}>\mathrm{t}$ values of $0.009,0.016,0.046$ and 0.001 for ATM's and Cards, mobile and 
internet banking and finally funds transfer system respectively. This is because each of these significant values are less than 0.05 .

Table 4: Regression Model Coefficients

\begin{tabular}{|c|c|c|c|c|c|c|}
\hline \multicolumn{7}{|c|}{ Coefficients $^{a}$} \\
\hline \multirow{2}{*}{\multicolumn{2}{|c|}{ Model }} & \multicolumn{2}{|c|}{$\begin{array}{l}\text { Unstandardized } \\
\text { Coefficients }\end{array}$} & \multirow{2}{*}{$\begin{array}{l}\text { Standardized } \\
\text { Coefficients } \\
\text { Beta }\end{array}$} & \multirow[t]{2}{*}{$\mathrm{t}$} & \multirow[t]{2}{*}{ Sig. } \\
\hline & & B & Std. Error & & & \\
\hline \multirow[t]{5}{*}{1} & (Constant) & -.661 & 3.015 & & -0.22 & .828 \\
\hline & LNATMC & 1.268 & .464 & 1.469 & 2.733 & .009 \\
\hline & LNOB & .272 & .107 & .261 & 2.542 & .016 \\
\hline & LNMB & .146 & .071 & .245 & 2.056 & .046 \\
\hline & LNFTS & .365 & .058 & .237 & 6.293 & .001 \\
\hline
\end{tabular}

The following regression equation is derived;

LNNIR $=-0.66+1.267$ LNATMC +0.272 LNMB +0.146 LNOB+0.365 LNFTS

This equation has coefficient values next to each technology-based financial innovation product used by banks to earn income. Its interpretation is as follows;

Coefficient for LNATMC $=1.267$ implies that holding LNMB, LNOB and LNFTS constant, a 1\% increase in the income generated from ATM's and cards will translate into a $1.267 \%$ increase in Non-Interest Income of commercial banks. Coefficient for $\mathrm{LNMB}=0.272$ implies that holding LNATMC, LNOB and LNFTS constant, then a $1 \%$ increase in income generated from mobile banking will translate to a $0.272 \%$ increase in NonInterest Income of commercial banks.

Coefficient for $\mathrm{LNOB}=0.146$ implies that holding LNATMC, LNMB and LNFTS constant, a $1 \%$ increase in income generated from online banking will translate to an increase in Non-Interest Income by $0.146 \%$. Coefficient for LNFTS $=0.365$ implies that holding LNATMC, LNMB and LNOB constant, a $1 \%$ increase in income generated from funds transfer systems will result to an increase in Non-Interest Income of banks by $0.365 \%$.

\section{Conclusion and Recommendations}

This study finds that an increase in the mount of income generated from financial innovation products positively and significantly affects non-interest income and recommends all stakeholders in banks should take any investments made towards technology based financial innovation products as a strategy to improve the amount of income they earn from non-interest sources. This comes at a time when technology and finance are merging so much so that the traditional branched banking system is slowly being replaced by digital banking. Soon, the banking industry will be taken over by these financial innovations, which will generate most of non-interest income. More 
specifically, the study recommends stakeholders of commercial banks to invest in ATM's and cards such as the debit and credit cards in an effort to earn more income through them. An increase in the number of ATM locations, addition of more security features to the cards and promotion of plastic money transactions in the market would translate to an increase in demand for these cards. With this demand satisfied, commercial banks are bound to have a significant improvement in their non-income interest since the higher number of ATM's and cards will facilitate an increase in the number of transactions that take place which in turn translates to an increase in the amount of fees collected from these transactions. An investment in this technology based financial innovation is therefore critical.

An investment in mobile and online banking platforms is also highly recommended by this study. The usage of these alternative banking platforms has been increasing over the years as indicated by a steady increase in the amount of income generated from them. This study found that an increase in this income has a statistically and significant effect on non-interest income earned, making an investment towards it critical. Mobile and online banking services appeal most to the youthful population who form a major demographic those banks are targeting. This population is on the move, technologically empowered and relies on hand held devices and internet to run their lives. Finally, the study also found a significant positive effect on the amount of income earned from funds transfer systems such as RTGS and EFT. This therefore implies that an investment in this technology based financial innovation is highly recommended by the study as it would lead to a significant increase in non-interest income earned by commercial banks.

This study was based on secondary data sourced from Central Bank of Kenya, which collates the information from all banks. However, specific data like number of transactions, deposits or fees charged by every commercial bank would have been more helpful in analyzing the level of adoption of the technology based innovations across different banks. Moreover, primary data sourced from key stakeholders in the industry through techniques like in depth interviews would have gone a long way in qualifying the quantitative secondary data collected.

The study also considered only four technology based financial innovations in its analysis. It is important to note that there are other sources of non-interest income that are technology based and have just been incorporated by commercial banks such as funds collecting devices for example mobile VISA, Pesa Link and dedicated applications for diaspora banking. Funds collected from their use also forms part of non-interest income not considered by this study. The study recommends future studies to consider a different time frame for purposes of comparing results. Studies can therefore be framed using the same topic but covering more than 10 years. This will 
provide the researcher more data points that can further test the accuracy of the regression model used.

\section{References:}

1. Akello, M. J. (2011). Determinants of financial innovation and its impact on financial performance of microfinance institutions in Kenya. Unpublished MBA project: University of Nairobi. Nairobi

2. Al-Jabri, I. M., \& Sohail, M. S. (2012). Mobile banking adoption: Application of diffusion of innovation theory. Journal of Electronic Commerce Research, Vol. 13, No. 4, pp. 379-391

3. ATM Benchmarking Study 2016 and Industry Report, (2016). $\begin{array}{llll}\text { Retrieved } & 11 & \text { September } & 2017\end{array}$ https://www.accenture.com/_acnmedia/PDF-10/Accenture-BankingATM-Benchmarking-2016.pdf

4. Baskerville, R., Bunker, D., Olaisen, J., Pries-Heje, J., Larsen, T. J., \& Swanson, E. B. (2014, June). Diffusion and Innovation Theory: Past, Present, and Future Contributions to Academia and Practice. In International Working Conference on Transfer and Diffusion of IT (pp. 295-300). Springer, Berlin, Heidelberg.

5. Beck, T., Chen, T., Lin, C., \& Song, F. M. (2016). Financial innovation: The bright and the dark sides. Journal of Banking \& Finance, 72, 28-51.

6. Central Bank of Kenya (2016). FinAccess National Survey 2013: Profiling developments in financial access and usage in Kenya, Nairobi.

7. Chen, C. R., Huang, Y. S., \& Zhang, T. (2017). Non-interest Income, trading, and bank risk. Journal of Financial Services Research, 51(1), 19-53.

8. Christensen, C. M., McDonald, R., Altman, E. J., \& Palmer, J. (2016). Disruptive Innovation: Intellectual History and Future Paths. Harvard Business School.

9. Damankah, B. S., Anku-Tsede, O., \& Amankwaa, A. (2014). Analysis of non-interest income of commercial banks in Ghana. International Journal of Academic Research in Accounting, Finance and Management Sciences, 4(4), 263-271.

10. DeYoung, R., \& Rice, T. (2004). Noninterest income and financial performance at US commercial banks. Financial Review, 39(1), 101127.

11. Frame, W. S., \& White, L. J. (2014). Technological change, financial innovation, and diffusion in banking. Journal of Banking \& Finance, 72, 328-371. 
12. Gichure, K. S. (2015). The relationship between non-interest income and financial performance of commercial banks in Kenya International Journal of Finance and Accounting. 1(2), 35-47.

13. Githakwa, P. W. (2011). The relationship between financial innovation and profitability of commercial banks in Kenya, Unpublished Doctoral Dissertation, University of Nairobi, Kenya).

14. Greenbaum, S. I., Thakor, A. V., \& Boot, A. (Eds.). (2015). Contemporary financial intermediation. Academic Press.

15. HE, G. S., \& XU, J. (2010). Non-interest income business and countermeasures for listed commercial banks in China [J]. Research on Financial and Economic Issues, 5 (10), 114-163.

16. Iwedi, M., \& Igbanibo, D. S. (2015). Modelling financial intermediation functions of banks: Theory and empirical evidence from Nigeria. Journal of Finance and Accounting, 6(18), 159-174.

17. Jack, W., Suri, T., \& Townsend, R. M. (2010). Monetary theory and electronic money: Reflections on the Kenyan experience. Research on Financial and Economic Issues, 5(10), 245-357.

18. Kagumya, P. K. (2011). Factors affecting non-interest income in commercial banks in Uganda: A case of commercial banks in Uganda (Doctoral dissertation, Makerere University).

19. Kamau, P. N. (2014). The effect of cashless transactions and financial trading income on non-funded income in commercial banks in Kenya. Unpublished MBA project. University of Nairobi. Nairobi

20. Kaminski, J. (2011). Diffusion of innovation theory. Canadian Journal of Nursing Informatics, 6(2), 1-6.

21. Laeven, L., Levine, R., \& Michalopoulos, S. (2015). Financial innovation and endogenous growth. Journal of Financial Intermediation, 24(1), 1-24.

22. Lee, C. C., Yang, S. J., \& Chang, C. H. (2014). Non-interest income, profitability, and risk in banking industry: A cross-country analysis. The North American Journal of Economics and Finance, 27, 48-67.

23. Malaquias, R. F., \& Hwang, Y. (2016). An empirical study on trust in mobile banking: A developing country perspective. Computers in Human Behavior, 54(2), 453-461.

24. Mugane, C. (2015). The effect of financial innovations on the financial performance of commercial banks in Kenya. Unpublished MBA project. University of Nairobi. Nairobi

25. Mwangi, E. W. (2014). The effect of financial innovations on nonfunded income of commercial banks in Kenya. Unpublished MBA project. University of Nairobi. Nairobi 
26. Mwinzi, (2014). The effect of financial innovation on economic growth in Kenya. Unpublished MBA project. University of Nairobi. Nairobi

27. Nagy, D., Schuessler, J., \& Dubinsky, A. (2016). Defining and identifying disruptive innovations. Industrial Marketing Management, 57, 119-126.

28. Ngari, J. M. K., \& Muiruri, J. K. (2014). Effects of financial innovations on the financial performance of commercial banks in Kenya. Unpublished Undergraduate project. United States International University-Africa. Nairobi.

29. Njeri, K. O. (2013). Effects of financial innovation on the financial performance of deposit taking SACCOs in Nairobi County. Unpublished MBA project. University of Nairobi. Nairobi

30. Norden, L., Buston, C. S., \& Wagner, W. (2014). Financial innovation and bank behavior: Evidence from credit markets. Journal of Economic Dynamics and Control, 43, 130-145.

31. Okiro, K., \& Ndungu, J. (2013). The impact of mobile and internet banking on performance of financial institutions in Kenya. European Scientific Journal, 9(13), 100-135.

32. Shaikh, A. A., \& Karjaluoto, H. (2015). Mobile banking adoption: A literature review. Telematics and Informatics, 32(1), 129-142.

33. Siebert, R. B. (2017). A structural model on the impact of prediscovery licensing and research joint ventures on innovation and product market efficiency. International Journal of Industrial Organization, 54, 89124.

34. Williams, B. (2016). The impact of non-interest income on bank risk in Australia. Journal of Banking \& Finance, 73, 16-37.

35. Worku, G. (2010). Electronic-banking in Ethiopia-practices, opportunities and challenges. Journal of internet Banking and commerce, 15(2), 10-51.

36. Yee-Loong Chong, A., Ooi, K. B., Lin, B., \& Tan, B. I. (2010). Online banking adoption: an empirical analysis. International Journal of Bank Marketing, 28(4), 267-287. 